\title{
Conceptual Awareness of Secondary School Teachers Regarding Peace Education: Analysis
}

${ }^{1}$ Sufi Amin, ${ }^{2}$ N. B. Jumani, ${ }^{3}$ Sheikh Tariq Mahmood

\begin{abstract}
Peace education is a key process for creating peace and devastating conflict and violence. Therefore, peace education promotes the knowledge, skills, attitudes as well as values that pursue to convert individual's mindsets, attitudes as well as behaviours. So, peace education is a key instrument for developing a culture of peace and a plan which has been used a large number of nations to stop violent and fatal conflicts. The objectives of the study were: (i) to examine the conceptual awareness of secondary school teachers regarding knowledge component of peace education in Khyber Pakhtunkhwa, Pakistan.(ii) To examine the awareness of secondary school teachers regarding the skills and attitude of peace education in Khyber Pakhtunkhwa, Pakistan. All secondary school teachers of Khyber Pakhtunkhwa were the population of the study. According to the nature of the study the researcher selected 320 secondary teachers from different districts. A self-developed questionnaire was used as a research tool. All statements on the questionnaire were related to conceptual awareness of secondary school teachers regarding peace education. The validity and reliability of the research instrument were accurately confirmed. The data were analyzed through SPSS (version 20). The findings and conclusions of the study showed that most of male secondary school teachers were aware about the three components of peace education. Majority of female secondary school teachers were not aware about the components of peace education.
\end{abstract}

Keywords: Peace Education, Knowledge, Attitude, Skills, Secondary Teachers

\section{Introduction}

The main effort of Peace education is that to end conflicts and encourage peace by providing an understanding regarding peace and develop an attitude for examining peace. According to Fountain, education is a key mechanism to boost knowledge regarding peace education,(Fountain, 1999). It has been delivered by numerous nations in their educational systems, programs as well as objectives. These reasons are the basic subjects of each and every peace education program

\footnotetext{
${ }^{1}$ PhD Scholar, Education Department, IIUI, Pakistan Email: sufiamin777@yahoo.com

${ }^{2}$ Dean, Faculty of Social Sciences, IIUI, Pakistan

${ }^{3}$ Assistant Professor, Department of Education, IIUI, Pakistan
} 
to be formed contrarily contingent on their determinations, (Salomon, 2011).So, the contents of peace education are quite unclear amongst specialists, regarding what should be incorporated in peace education, (Hakvoort, 2010). The United Nations organization was established in 1945, its main concern is to promote the concept of peace in all over the world to stop the conflicts and continue peace but people sustained to be suffering by huge scale. It is becoming the catastrophe for the United Nations to convey their mandate. Furthermore, 62conflicts in Africa, 41 in Latin America, 31 in Asia, 19 in Europe as well as 15 in the Middle East, so 168 wars were fought in different parts of the world. Obviously, these warsinterrelated evidences as well as facts, individual's wants for a nonviolent creation could not be completely understood throughout the twentieth century. So, it was the catastrophe of the twentieth century, that an individual cross the threshold of this century with a newcomer of carrying the end of conflict, but this century finished as being the world's goriest one, with a demise peal of 110 million fatalities of conflict, (Henry, 2007). So as to clash the philosophy of violence that permeates our culture, the upcoming cohort justifies a drastically diverse education, one does not lionize conflict, but teaches for nonviolence, peacefulness and worldwide collaboration. It's a wide-ranging arena as well as can be problematic to explain. Basically, one can say that, it's authorizes beginners with the knowledge, skills, attitudes as well as values compulsory to finish battles, discrimination and encourage a philosophy of peace. It is the practice of gaining the values, knowledge as well as emerging the outlooks, abilities as well as performances to alive in congruence with self, others as well as with the likely situation, (Henry, 2007).

\subsection{Statement of Problem}

It is a rigorous point, that the government of chaos as well as misunderstanding in the world is moving the youngsters' cleared concentrations. Youngsters certainly captivate the essence of viciousness in the situation and will quickly develop into the upcoming people of the perpetrator of clashes. So, it is necessity to encourage peace in the mind of children to risen as a crucial concern to be spoken. Therefore, it can be communicated in wide range, methods and ways at diverse stages; however the prevailing study has engrossed on proper way of education at Secondary school level in Khyber Pakhtunkhwa, Pakistan. The selection of secondary school level is centered on the datum is the rudimentary stage of youngsters and their educational career, so, it delivers a scenario for the improvement of peaceable outlooks as well as performances for the future of Pakistan. Finally, it delivers a large provision to cultivate a peaceable culture in al over the word as well as teacher is the central performer in stimulating peace and non-violent principles amongst the scholars. So, it's 
essential to examine to what degree the secondary school teachers were conscious regarding peace education. The main effort of this preparation is to search the "Conceptual Awareness of Secondary School Teachers regarding Peace Education: An Analysis".

\subsection{Objectives of the study}

1. To examine the conceptual awareness of secondary school teachers regarding knowledge of peace education Khyber Pakhtunkhwa, Pakistan.

2. To examine the awareness of secondary school teachers regarding skills and attitude of peace education in Khyber Pakhtunkhwa, Pakistan.

\subsection{Research Questions}

1. What is the extent of conceptual awareness of secondary school teachers regarding knowledge of peace education in Khyber Pakhtunkhwa, Pakistan?

2. What is the extent of conceptual awareness of secondary school teachers regarding skills and attitude of peace education in Khyber Pakhtunkhwa, Pakistan?

\section{Literature Review}

Peace is derived from the Italian word 'Pax', and its meaning is an agreement, discrepancy and treaty to finish the battle or else some clash and fight between two people, two countries and two aggressive set of peoples, (Khemananda, 1996).Oxford Learner's Dictionary defined peace in such a way that," It is a state in which there is no conflict or viciousness in a nation. Or the situation of presence tranquil and noiseless and the situations of existing in relationship with someone lacking of quarreling, it is called peace". It is a kind of training which influences in the norms, values as well as attitudes of the students, it could convey regarding the encouraging situation for human being. A wide range of philosophies, descriptions and practices are mentioned in peace education works. Since both 'peace' and 'education' is concept lacking a little solid and complete importance, peace education is somewhat difficult to discover extensive treaty regarding, what it is in reality, (Haavelsurd, 2008).Yet, it is a program of many fields in nature as well as concealment of a diversity of viewpoints and methods concerning, particularly, to philosophy, attention, subjects, performs and even aims, (Bar-Tal, 2002).

In the early of the $1980 \mathrm{~s}$, the danger of atomic battle provoked, and teachers from all over the world caution of imminent destruction in forthcoming. Therefore, Reardon is peace scholar, who highlighted a new pattern of truthfulness as well as the totality alongside with the dominant part of the ecosystem in the field of peace education, (Reardon, 1988). He discussed that the 
concealment principles of education should be precaution, unease as well as an obligation, and the basic perceptions of peace education should be universal nationality and benevolent associations. According to Ian Harris a universal method to peace education is that it could relate to public education, schools and institution of higher education. So, the main elements of such training are supportive knowledge, self-governing community, decent understanding, as well as perilous philosophy, (Harris, 2008). Castro \& Galace, (2010) discussed the following components of peace education.

\section{Knowledge}

Holistic Concept/Content Areas: Peace is not only the nonexistence of straight or corporal violence, while it is the existence of circumstances of happiness, collaboration and the link of people with their natural domains.

Conflict and Violence: It is the usual portion of individual's societal life, however, they develop glitches of conflict contingent on the approaches of war determination recycled.

Disarmament: In this beginner can be presented with the objective of eliminating conflict as well as dropping worldwide armed militaries and weapons.

Nonviolence: In this beginner can be presented the logical as well asmystical foundations of fierceness and its effectiveness as a technique to outcome alteration. Furthermore, the circumstances of persons as well assets, who have encouraged nonaggression as a viewpoint and technique, can be studied.

Conflict Resolution, Transformation and Prevention: Scholars can study the current techniques of solving clashes peacefully as well as how it can be smeared into their day to day life. It can change the study how a war can be determined and changed into a condition that is further anticipated.

Human Solidarity: Therefore, numerous groups quandary composed opposing spiritual, social, native and country wide collections. Every person has mutual rudimentary requirements and aims to communal association in a dependent social or universal society. Pupils can stare at how to upsurge inter-religious, intercultural as well as inter-group faith, understanding, reverence as well as collaboration, in addition to dishearten typecasting and bias.

Development Based on Justice: The students can be completely judgemental conscious of the certain ties as well as disastrous significances of organisational strength. It requires comprehending that the growth is not financial tumour only, but also the unbiased distribution of its berries. 
Democratization: Democratization is the main thing for students to comprehend as well as it delivers the situation inside which is the ultimate rights, wellbeing and requirements for people.

Sustainable Development: it very important for students to comprehend the reliant association between human being and the natural situation as well as realise the variations, which is essential to confirm the happiness of the world's environments, and it can carry on to meet upcoming as well as existing requirements. They must revive the understanding of our native inhabits, who have continuously appreciated environment.

\section{Attitudes / Values}

Some of the attitudes which are essential to be developed are:

Self-respect: It is an intellect of their personal value as well as a sagacity of arrogance in their personal specific societies, traditional and domestic training and an intellect of their personal supremacy as well as golly. It can assist them to subsidise in the direction of optimistic modification.

Respect for Others: It is the sagacity of the value as well as integral self-esteem of new individuals, containing those with communal, spiritual, traditional and domestic upbringing altered from their personal.

Respect for Life/Nonviolence: The esteeming of social life as well as negation to answer to the antagonist or else battle condition with furious, inclination for peaceful procedures, for example cooperative problem solving as well as further optimistic procedures as in contradiction of the practice of corporal strength and armaments.

Gender Equality: To give equivalent opportunities to women as well as men, and to be allowed from exploitation, mistreatment as well as viciousness.

Compassion: The understanding of problematic circumstances as well as misery of new people and performing with profound understanding and compassion in the direction of those, who are side-lined or omitted.

Global Concern: It is helpful for the entire society excelling or else working elsewhere for apprehension. Which they have for their country or native/cultural society.

Ecological Concern: It means to be compassionate for the normal situation, inclination for supportable incarnate as well as a humble existence. 
Cooperation: The esteeming of accommodating developments as well as the opinion of functioning self-possessed in the direction of the recreation of mutual aims.

Openness/Tolerance: The openness is a procedure of development as well as modification in addition to enthusiasm to attitude and obtain other individual's thoughts, views as well as involvements with a dangerous but vulnerable awareness; concerning the ridiculous multiplicity of our biosphere's mystical civilizations, values as well as procedures of appearance.

Justice: It is performed with wisdom of justice in the direction of others, continuation the opinion of equivalence as well as refusal of each and every procedure of mistreatment and domination.

Social Responsibility: The inclination is an accomplishment to subsidise to the determining of a civilization categorised by integrity, peacefulness as well as happiness; the sagacity of accountability in the direction of contemporary as well as upcoming peoples.

Positive Vision: It is the imaging part of the upcoming, they desire with a sagacity of confidence as well as dogging, its understanding in techniques that they can.

\section{Skills}

Some of the skills that essential to be developed are:

Reflection: To use the meditative philosophy as well as thinking, it can excavate their sympathetic of themselves and their connectedness to others peoples who are living in this world.

Critical Thinking and Analysis: The skill to tactical matters with a vulnerable but serious awareness, perceptive how to investigation, enquiry, estimate and understand confirmation, the capability to distinguish and contest biases and unnecessary statements in addition to adjustment thoughts in the expression of confirmation as well as balanced influences.

Decision-making: The ability to examine difficulties, improve alternate clarifications, examine different resolutions allowing for compensations as well as shortcomings, and having reached at the desired conclusion, capacity to formulate a strategy for the employment of the result.

Imagination: The constructing and visualising innovative examples and different chosen techniques of existing as well as concerning. 
Communication: Attending thoughtfully and with understanding, in addition to the capacity to direct philosophies as well as requirements obviously and in a non-violent way.

Conflict Resolution: The capacity to examine clashes in an objective as well as efficient approach and to propose a variety of peaceable clarifications. War determination assistances consist of suitable decisiveness, negotiation, vigorous attending as well as combined problem-solving. Conversation assistances are significant initial helps in battle determination.

Empathy: It is the capacity to understand the outlook of alternative individual or else group as well as to the atmosphere, what that individual and group sensation. It is ability that assistances in enlargement the beginners' personal view points, particularly in the examination of reasonable and beneficial choices.

Group Building; To work obligingly with one another so as to attain shared objectives. Team work and group-building are assisted by joint confirmation and reassurance by the supporters. The hypothesis is that everybody has approximately to subsidize, each person is part of the clarification.

\subsection{Research Design}

\section{Research Methodology}

The nature of the study was descriptive as it was concerned with the existing status of the subject under investigation. Due to limited time and the expended nature of the investigation the study was delimited to the Secondary Teachers of public sector in a District.All secondary school teachers of Khyber Pakhtunkhwa were the population of the study. According to the nature of the study the researcher selected 320 secondary teachers from different districts.A multiple choice questionnaire was developed and every statement was followed by three statements.All statements on the questionnaire were related to conceptual awareness of secondary school teachers regarding peace education. The respondents were given the option to choose the one that best validate the main statement in their opinion, exploring the conceptual awareness of respondents about peace education. The validity and reliability of the research tool was sufficiently ensured.The instrument was directed to the sample participants merely afterward full validity as well as confirmation checks.

\section{Data Analysis and Interpretation}

The data were analyzed through SPSS (version 20). The analyzed data were presented in the form of tables. 
Table 1

Showing the overall results of participants about peace education

\begin{tabular}{ccccc}
\hline S.No & Variables & N & Yes (\%) & No (\%) \\
\hline 1. & Knowledge & 320 & 47.62 & 52.38 \\
2. & Skills & 320 & 39.25 & 60.75 \\
3. & Attitudes/Values & 320 & 55.43 & 44.57 \\
\hline \multicolumn{5}{c}{ overall percentage } \\
\hline
\end{tabular}

Table 1 revealed that, $47.62 \%$ teachers were given their response in 'yes' towards knowledge, while $52.38 \%$ were given their response in 'no' towards knowledge.39.25\% teachers were given their response in 'yes' about skills while $60.75 \%$ were given their response in 'no' about skills. $55.43 \%$ teachers were given their response in 'yes' towards attitudes while $44.57 \%$ were given their response in 'no' about values. So, the total percentage interprets that $46.55 \%$ teachers were give positive response towards the main components of peace education while $53.45 \%$ of the teachers were given negative response towards main components of peace education. Thus, it decided that most of teachers were not conscious about the main components of peace education.

Table 2

Presenting the mean values, std. Deviation as well as Std. Error of mean of the Components of Peace Education

\begin{tabular}{lcccc}
\hline Components & $\mathrm{N}$ & Mean & Std. Deviation & Std. Error Mean \\
\hline Knowledge & 320 & 4.69 & 1.76 & .078 \\
Skills & 320 & 3.23 & 1.65 & .084 \\
Attitudes/Values & 320 & 4.75 & 1.79 & .074 \\
\hline
\end{tabular}

According to table 2, the mean value of knowledge is 4.69 , a skill is, 3.23 as well as the attitudes/values is 4.75 . Thus, it decided that most of secondary school teachers were conscious about knowledge as well as attitudes compared with skills components of peace education. 
Table 3

Presenting the $t$ test results on "knowledge" component of peace education in term of gender

\begin{tabular}{cccccccc}
\hline Gender & $\mathrm{N}$ & Mean & SD & $\begin{array}{c}\text { Std. } \\
\text { Error }\end{array}$ & Df & t value & $\begin{array}{c}\mathrm{p} \\
\text { value }\end{array}$ \\
\hline Female & 150 & 3.48 & 1.421 & 4.76 & 320 & 0.084 & 0.0001 \\
Male & 170 & 4.453 & 1.643 & & & 0.107 & \\
\hline
\end{tabular}

Table 3 reflects that, the mean score of male secondary school teachers higher than female secondary school teachers towards its element 'knowledge'. 4.453 is its $t$ value which is significant at 0.05 level of significance. Thus, it's decided that male secondary school teachers were aware if we compare with female secondary school teachers, towards its element "knowledge.

Table 4

Presenting the $t$ test results on "Attitudes/Values" Component of Peace Education in term of Gender

\begin{tabular}{cccccccc}
\hline Gender & $\mathrm{N}$ & Mean & SD & $\begin{array}{c}\text { Std. } \\
\text { Error }\end{array}$ & Df & t value & $\begin{array}{c}\mathrm{p} \\
\text { value }\end{array}$ \\
\hline Female & 150 & 4.11 & 1.742 & 4.98 & 320 & 0.063 & 0.0001 \\
Male & 170 & 4.528 & & & & 0.166 & \\
\hline
\end{tabular}

Table 4 reflected that, the mean score of male secondary school teachers higher than female secondary school teachers towards its element 'attitudes/values'. 4.528 is its $\mathrm{t}$ value which is significant at 0.05 level of significance. Thus, it's decided that male secondary school teachers were aware if we compare with female secondary school teachers, towards its element "attitudes/values'.

Table 5: Presenting the $t$ test results on "Skills" Component of Peace Education in terms of Gender

\begin{tabular}{cccccccc}
\hline Gender & $\mathrm{N}$ & Mean & SD & $\begin{array}{c}\text { Std. } \\
\text { Error }\end{array}$ & Df & t value & $\begin{array}{c}\mathrm{p} \\
\text { value }\end{array}$ \\
\hline Female & 150 & 4.01 & 1.213 & 4.70 & 320 & 0.042 & 0.0001 \\
Male & 170 & 4.82 & 1.834 & & & 1.153 & \\
\hline
\end{tabular}

Table 5 reflected that, the mean score of male secondary school teachers higher than female secondary school teachers towards its element 'Skills'. 4.828 is its $t$ value which is significant at 0.05 level of significance. Thus, it's decided that male secondary school teachers were aware if we compare with female secondary school teachers, towards its element "Skills". 


\section{Discussion}

The key concern of this investigation was towards the conceptual awareness of secondary school teachers about peace education. The researcher has measured the three basic components of peace education. The result of the investigation exposed that a large number of the teachers were not aware about the element of peace education. Whereas, it's shown that male secondary school teachers have better consciousness if compared with female secondary school teachers. The findings of the current study were a sharp contrast with the findings of the research carried out by Makoni (2015), Mishra (2011) and Bratlett (2009), who conducted an investigation regarding peace education practices in preservice teachers training programs, and concluded that teachers have positive attitudes about the peace education practices.

\section{Conclusion}

The main conclusions of the study have demonstrated that the most of male secondary school teachers were aware about the three components of peace education. While the most of female secondary school teachers were not aware about the components of peace education. This study also demonstrated that the majority of the respondents were not aware to peace education. The mean score of male secondary school teachers on the components of peace education was higher than female secondary school teachers, as well as $p$ value was less than 0.05.It shows that there was an important difference between mean score in favour of female secondary school teachers. So, total percentage shown that $60.20 \%$ secondary school teachers were not aware with peace education and $39.80 \%$ of secondary school teachers were aware about the components of peace education.

\section{Recommendations}

The main recommendations of the study were:

1. All formal, informal, and non-formal modes of education may be structured by the Government on the philosophy of peace and peace education.

2. A Peace Education University may be established by the United Nations Organization in each third world country.

3. Peace education as a discipline and as a subject may be incorporated in the mainstream education system and be made a compulsory part of the course syllabus at every stage of the educative process.

4. Teachers as well as students may be imparted training in peace-promoting skills, and in peace education. Such trainings may equip the trainee with the knowledge, skills, and attitudes compendium of peace education. 


\section{References}

Aharoni, A. (2008). Peace education and culture system in the Middle East and beyond. Encyclopedia of Peace Education.

Bar-Tal, D. (2002). The elusive nature of peace education: The concept,principles and practices around the world. London: Lawrence Erlbaum Associates.

Bartlett, T. (2009).Teaching Teachers to Teach Peace: A Reflective Pre-Service Case Study (Master of Arts). University of Toronto.

Castro, L. N., \&. G. (2010). Peace Education: A pathway to a culture of peace. Quezon City: Miriam College.

Fountains, S. (1999). Peace Education in UNICEF. New York:UNICEF.

Haavelsrud, M. (2008). Conceptual perspective in peace education. Encyclopedia of Peace Education.

Hakvoot, I. (2010). Peace Education in Region of Tranquality. In G. S. Cains, Handbook on peace education (pp. 287-301). Psychology Press.

Harris, I. (2004). Challenges for Peace Educators at the Beginning of the $21^{\text {st }}$ Century, Social Alternatives.

Henry, E. (2007). Building a Global Civic Culture: Education for an Interdependent World. Syracuse, N.Y: Syracuse University Press.

Khemananda, B. (1998). The Buddhist Concept of Peace. Calcutta: Lazo Print.

Makoni, R. (2015). Peace education in Zimbabwean Pre-service Teacher Education : A Critical Reflection. Uir.unisa.ac.za. Retrieved 14 December 2015, from http://uir.unisa.ac.za/handle/10500/18975

Mishra, L. (2011). Pre-service teacher training for peace education.International Journal Of Peace And Development Studies, 2(7), 203-210. Retrieved from http://www.academicjournals.org/journal/IJPDS/article-full-textpdf/757FA7141079

Reardon, B. (1988). Educating for global responsibility: Teacher design curricula for peace education. New York: Teacher College Press.

Salomon, G. (2011). Four major challenges facing peace education in regions of intractable conflict. Peace and Conflict: Journal of Peace Psychology, 17(1), 46-59. http://dx.doi.org/10.1080/10781919.2010.495001 